\title{
Histopathology of the gills, livers and kidney of Clarias gariepinus (Burchell, 1822) exposed to sniper 1000EC under laboratory conditions
}

\author{
MUSA I. ABUBAKAR, ${ }^{1}$ IBRAHIM AdESHinA, ${ }^{2}$ I KILILU ABDUlRAHEEM, ${ }^{3}$ \\ SOMIRA ABDULSALAMI ${ }^{4}$
}

${ }^{1}$ Department of Aquaculture and Fisheries, Faculty of Agriculture, University of Ilorin, P.M.B. 1515 Ilorin, Kwara State, Nigeria

${ }^{2}$ Department of Aquaculture and Fisheries, Faculty of Agriculture, University of Ilorin, P.M.B. 1515 Ilorin, Kwara State, Nigeria

${ }^{3}$ Department of Aquaculture and Fisheries Management, Faculty of Agriculture, federal university of Agriculture, P.M.B. 1313 Abeokuta, Ogun State, Nigeria

${ }^{4}$ Department of Biological Sciences, Fisheries and Aquaculture, College of Natural and Applied Sciences, Cresent University, P.M.B 2104, Abeokuta, Ogun State, Nigeria

Corresponding authors, email: abubakar.im@unilorin.edu.ng, adesina.i@unilorin.edu.ng, a.ikililu@yahoo.com, raheemsomrat@yahoo.com

Keywords Sniper 1000EC, histopathology, Clarias gariepinus, gills, livers and kidney

Abstract Indiscriminate use of Sniper 1000EC has become a serious problem among local fishermen in the Northern parts of Niger state. Juveniles of Clarias gariepinus (mean body weight $23.34 \pm 0.05 \mathrm{~g}$; mean standard length, $20.00 \pm 0.45 \mathrm{~cm}$ ) were subjected to 5 treatment levels of $0,5,10,15$ and $20 \mathrm{mg} / 1$. The tissue damages were observed majorly at 15 and $20 \mathrm{mg} / 1$ of sniper 1000EC exposed fish species. Oedema and hyperplasia were observed in the gills of the exposed groups. Hepatocellular steatosis and vacuolations were observed in the livers. Tubular nephrosis and hyperplasias of epithelial cells were also observed in the kidney. It is concluded that alterations in gills, livers and kidney of the exposed fish species were consequences of exposure to the toxicant (sniper 1000EC). It is recommended that the use of Sniper $1000 \mathrm{EC}$ by local fishermen be banned to save the aquatic environment from destruction.

\section{Obraz histopatologiczny skrzeli, wątroby i nerek suma afrykańskiego Clarias gariepinus (Burchell, 1822) narażonego na środek owadobójczy Sniper 1000EC w warunkach laboratoryjnych.}

Słowa kluczowe Sniper 1000EC, histopatologia, Clarias gariepinus, skrzela, wątroba i nerki

Streszczenie

Bezkrytyczne stosowanie Sniper 1000EC stało się poważnym problemem dla lokalnych rybaków w północnych częściach Nigru. Młode osobniki Clarias gariepinus (średnia masa ciała 23,34 $\pm 0,05 \mathrm{~g}$; średnia długość $20,00 \pm 0,45 \mathrm{~cm}$ ) przetrzymywano w warunkach laboratoryjnych w środowisku zawierającym 0, 5, 10, 15 i 20 mg/l środka Sniper 1000EC. Uszkodzenia tkanek obserwowano głównie przy najwyższych stężeniach (15 i $20 \mathrm{mg} / \mathrm{l})$. Obserwowano obrzęk i przerost skrzeli narażonych ryb. W wątrobie obserwowano stłuszczenie i wakuolację. 
W nerkach stwierdzono nefrozę i przerost komórek nabłonkowych. Wykazano, że zmiany w skrzelach, wątrobach i nerkach narażonych ryb były konsekwencjami narażenia na działanie insektycydu (Snajper 1000EC). Ze względu na dużą toksyczność zaleca się zakazać używania Sniper 1000EC.

\section{Introduction}

Histopathological changes have been widely used as biomarkers in the evaluation of the health of fish exposed to contaminants in laboratory animal (Wester, Canton, 1991; Thophon et al., 2003; Abubakar, Adeshina, 2019) and wild specimen (Hinton et al., 1992; Schwaiger et al., 1997; Tech, Adams, Hinton, 1997; Drishya, Binu-Kumari, Mohan-Kumar, Ambikadevi, Aswin, 2016). One of the great advantages of using histopathological biomarkers in environmental studies is that this category of biomarkers allows the examination of the target organs (Gernhofer, Pawet, Schramm, Muller, Triebskorn, 2001). Furthermore, the alterations found in these organs are clearer than functional ones (Fanta, Rios, Romao, Vaaianna, Freiberger, 2003). It also reveals signs of damage to animal health (Hinton \& Lauren 1990). The gills, being a respiratory organ of fish (Banerjee, 2007) is frequently in contact with external environment and thus vulnerable to aquatic toxicants (Abubakar, 2013). Studies have been conducted on histopathological changes in the gills, liver and kidney of fish exposed to various substances (Auta, 2001; Drishya et al., 2016; Abubakar, Adeshina, 2019) including pesticide which have been reported to cause pathological alteration in the exposed C. gariepinus (Auta, 2001). The liver ow $\mathrm{f}$ fish can be considered as a target organ to pollutants, alterations in its structure can be significant in the evaluation of fish health (Kolbasi, Burcu, Ucuncu, Onen, 2009).

Widespread application of various pesticides has aggravated the problem of pollution to aquatic environment. Due to these synthetic chemicals, environment has failed to keep its healthy characteristics. The insecticides of proven economic potentialities could not do well in the ecosystem when viewed on extra fronts since these revenue poisons, in a residual form or as a whole, get into the aquatic ecosystem. They cause a series of problems to aquatic organisms (Camargo, Martinez, 2007; Mastan, Ramayya, 2010; Drishya et al., 2016; Abubakar, Adeshina, 2019).

Sniper 1000EC (2, 3-dichlorovinyl dimethyl phosphate), a brand of dichlorvos, is contact acting and fumigant insecticide (Abubakar, 2013). Like all organophosphates, it kills insects and other target organisms because of its toxicity to the nervous system. This is achieved by inhibition of enzyme acetylcholinesterase (AchE) that breaks down acetycholine at the receptor site for partial uptake into the nerve terminal (Drishya et al., 2016). Without functioning AchE, accumulation of acetylcholine results in depolarizing block of muscle membrane, producing rapid twitching of involuntary muscles, convulsions, paralysis and early death (Camargo, Martinez, 2007; Mastan, Ramayya, 2010; Drishya et al., 2016; Abubakar, Adeshina, 2019). Indiscriminate use of Sniper 1000EC is common among local fishermen from Northern parts of Niger state.

The African catfish,Clarias gariepinus is an important food fish in Nigeria (Abubakar, 2012). Clarias gariepinus is not only the most predominant fish species raised in aquaculture in Nigeria, but has also served as an experimental model of aquatic vertebrate for two decades (Cavaco et al., 2001). Despite the indiscriminate use of Sniper 1000EC by local fishermen, there is a paucity of information on its toxicity.

The aim of the present study was to evaluate histological alterations in gills, liver and kidney of Clariasgariepinus (Burchell, 1822) exposed to sniper 1000EC under laboratory conditions. 


\section{Materials and Methods}

\section{Experimental fish and test chemical}

Juveniles of Clarias gariepinus (n 150, mean body weight $23.34 \pm 0.05 \mathrm{~g}$ ) were purchased from a reputable 36 fish farms in Ilorin, Kwara State, Nigeria. The samples were transported to the Central Laboratory, University of Ilorin in plastic container of $100 \mathrm{~L}$ capacity filled with water to two-third volume between 07:00 hours and 09:00 hours. They were held in large water baths of $160 \mathrm{~L}$ capacity and acclimated for 14 days to laboratory conditions. The top of water bath was covered with netted material to prevent jumping out of the fish. A slit was made at middle of the net to allow for feeding fish and cleaning of the bath. Feeding commenced two days after the arrival and stopped twenty-four hours before the commencement of the experiment. During acclimation, fish were fed twice daily (08:00 and 16:00 hours) with formulated feed (45\% crude protein, Table 1) at $5 \%$ body weight.

Table 1. Proximate composition of experimental diets

\begin{tabular}{|l|r|}
\hline \multicolumn{1}{|c|}{ Parameters } & Composition (\%) \\
\hline Moisture & 8.3 \\
\hline Crude protein & 45.0 \\
\hline Ash & 9.5 \\
\hline Crude lipid & 12.0 \\
\hline Crude fibre & 1.5 \\
\hline
\end{tabular}

The fishwere accepted and adapted to laboratory conditions for the 14 days. The water in the bath was changed daily and uneaten food and faecal matters were siphoned out. Water parameters were monitored two times daily at the hours of 08:00 and 18:00. The water temperature, DO and $\mathrm{pH}$ ranges throughout the experimental period were $24.1-25.7^{\circ} \mathrm{C}, 5.6-6.6 \mathrm{mg} / 1$, and $7.24-7.81$, respectively which were measured with the aid of mercury-in-glass thermometer, a digital DO meter (Model AVI-660, Labtech International Ltd, Heathfield, UK) and a digital pH-meter (Model Photoic 20, Labtech International Ltd, Heathfield, UK), respectively. Dead fish were also removed to minimize contamination of water.

Test chemical (2, 3-dichlorovinyl dimethyl phosphate), a brand of Dichlorvos with the trade name Sniper 1000EC (United Phosphorous Limited, UPL) was obtained from Minna central market and was used for the study. The test concentrations were prepared with reference to the Manual of Method in Aquatic Environment Research.

\section{Experimental design}

The experimental design was a complete randomized design. A total of one hundred and fifty (150) juvenile of Clarias gariepinus were randomly distributed into the tanks $(60 \times 38 \times$ $27 \mathrm{~cm}$ ) at a stocking rate of 10 fish per tank. The fifteen (15) tanks were assigned to 5 treatments comprises $0,5,10,15$ and $20 \mathrm{mg} / \mathrm{l}$. Dead fish from experimental groups were removed and dissected immediately for histological analysis while specimens from control were vivisected without anesthesia and subjected to histological analysis at the end of one- week experiment. 


\section{Histological procedures}

Samples of fish from both control and experimental groups were excised, rinsed in physiological saline and fixed in Bouin's fluid for 6, 12 and 8 hours respectively. The gills, livers and kidneys were subjected to micro techniques (Bucke, 1989; Adeshina, Jenyo-Oni, Emikpe, Ajani, Abdel-Tawwab, 2019). The tissues were dehydrated in an ethyl alcohol series of ascending concentrations, embedded in paraffin and sectioned at $5 \mu \mathrm{m}$ thickness. The tissues sectioned were stained with haematoxilin-eosin (HE). Stained slides were cleared in xylene and mounted in synthentic resin medium. The slides were examined under low power $(\times 4)$ objective and high power $(\times 10)$ objective with Tension Binocular microscope. Under extreme low power, the condenser was moved into a very low position to prevent the image of the lamp bulb from obscuring the image of the micrographs. Photomicrographs were then taken at low power $(\times 40)$ objective with Samsung ES25 4X Zoom Lens digital Camera and downloaded into a computer. Photomicrographs of control groups were compared with those of exposed groups under the guidance of a pathologist.

\section{Results}

\section{Histopathology of the gill}

No alterations were observed in the gills of the control (Figure 1A). The most common pathological changes in the gills of exposed fish species were fusion of lamellae, oedema and hyperplasia of the secondary lamellae (Figure 1B).

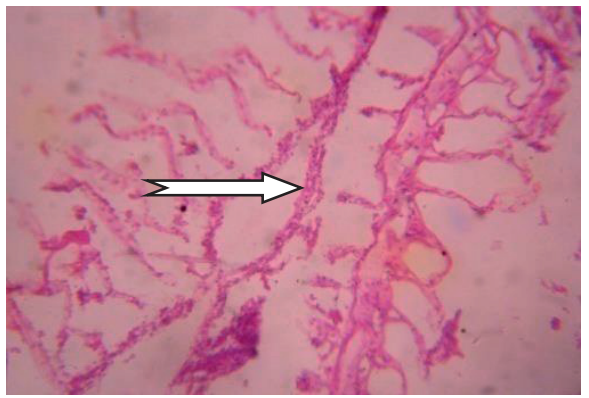

A

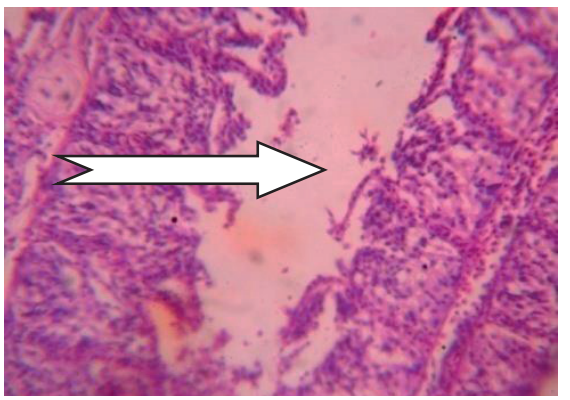

B

Showing normal appearance of the gill lamellae (A) and Photomicrograph of sections of the gill of Clarias gariepinus exposed to $20 \mathrm{mg} / 1$ of sniper 1000EC (B) showing fusion of lamellae, oedema and hyperplasia of interlamellae

Figure 1. Photomicrograph of a section of the gill from a control Clarias gariepinus

\section{Histopathology of the liver}

There were no abnormalities in liver of the control groups (Figure 2A . The pathologicalchanges in the liver tissues of the exposed fish species showed distortions with steatosis,vacuolations and necrosis. (Figure 2B). 


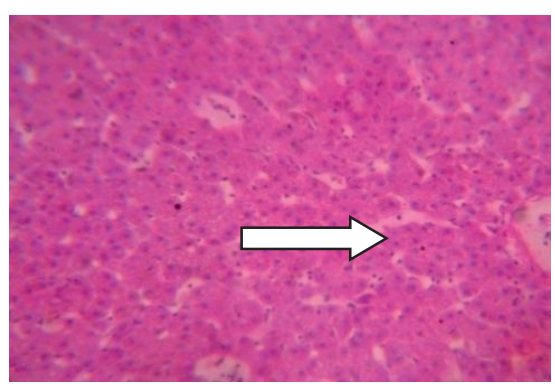

A

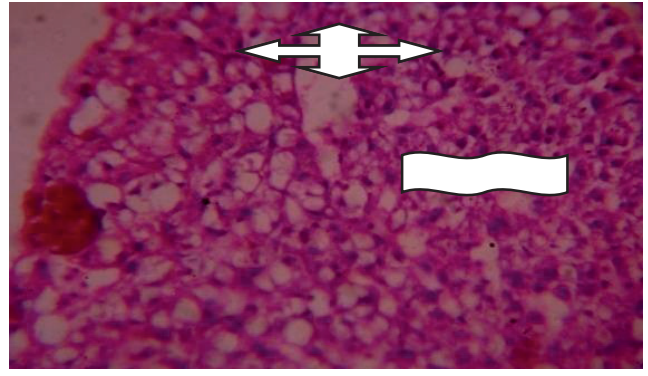

B

Showing normal appearance (A) and Photomicrographs of sections of the liver of Clarias gariepinus exposed to $15 \mathrm{mg} / 1$ of sniper 1000EC (B) showing steatosis $>$ vacuolation $\underset{2}{\Rightarrow}$ and necrosis

Figure 2. Photomicrograph of a section of the liver from a control Clarias gariepinus

\section{Histopathology of the kidney}

There were no observed distortions in the kidneys of the control group (Figure 3A).Exposed kidneys had marked cellularity of tubules infiltrated by lymphocytesand neutrophils. The interstitial were heavily infiltrated by inflammatory cells. The tubular cells were hypertrophic and the lumina contained armorphouseosinophilic materials (Figure 3B).

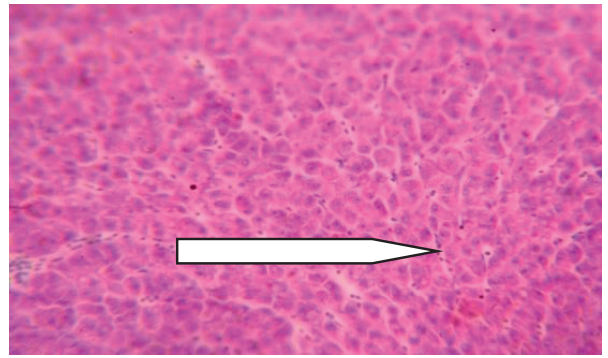

A

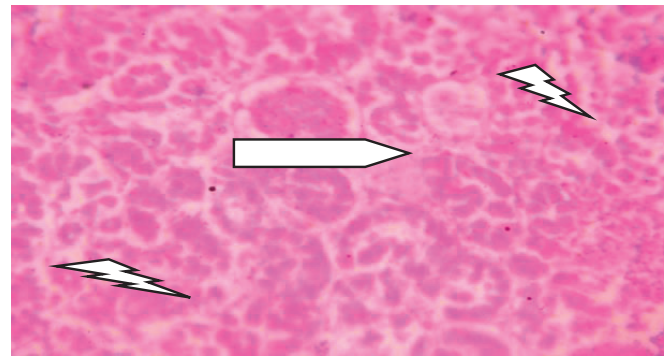

B

Showing homogeneous parenchyma tissues (A) and photomicrograph of sections of the kidney of Clarias gariepinus exposed to $20 \mathrm{mg} / 1$ of sniper 1000EC (B) showing tubular nephrosis and hyperplasia.

Figure 3. Photomicrograph of section of anterior kidney from a control Clarias gariepinus

\section{Discussion}

Gills are the primary corridor for molecular exchange between the internal milieu of fish and their external environment (Olson, 1996), such as gas transfer, acid-base regulation and ionic regulation (Eddy, 1982). The filament of gills and their secondary lamellae represent two general types of epithelium (Laurent, Dunel, 1980; Laurent, 1984) that contain three cell epithelia, the pavement, the chloride (ionocyce or mithochondria- rich) cells and the mucous cells, which are most prevalent. In some fish species, the gills contain microvillous or smooth surface lamellar 
pavement cells (Hossler, Harpole, King, 1986). Study of the gills in the control fish showed a typical structural organization of the lamella while gills from the fish exposed to the toxicant had several histological distortions, namely clumping/fusion, oedema and hyperplasia of the lamellae. The gill abnormalities observed in this study were similar to previous studies on fish gill morphology, which showed separation of the epithelial layers of secondary gill lamellae, deformation of secondary lamellae and degeneration of chloride cells accompanied by hyperplasia of undifferentiated cells in the primary lamellae (Daye, Garside, 1976; Chevailer, Gauthier, Moreau, 1985).

The oedema and hyperplasia in the gills of the exposed fish might be due to acute inflammatory nature of the lesion induced in such gills by the sniper 1000EC. Eller (1970) reported hyperplasia of gill lamella epithelium as findings suggestive of toxicity in several fish species following exposure to several toxicants. Oedema with epithelial separation was reported by (Eller, 1971; Van Valin, Andrews, Eller, 1968) as additional gill change in fish exposed to toxicants. Epithelia sodium pump failure might be responsible for gill oedema (Mitchel, Cotran, 2004). The hyperplasia might in addition be an attempt to increase blood supply to compromised gill in order to increase blood oxygenation. (Gabriel, Amakiri, Ezeri, 2007). This could be a compensatory maechanism in the exposed fish to counter hypoxia sequel to edema and obliterated inter-lamellae space, which impeded gaseous exchange across such gills (Gabriel et al., 2007). Oedema has been reported to increase the diffusion distance between gill capillaries and epithelial cells, thereby increasing internal diffusion resistance, which is a major factor that inhibits gaseous exchange across the affected gills (Turala, 1983).

The lamellar fusions are defense mechanisms that reduce the branchial superficial area in contact with the toxicant. These mechanisms also increase the diffusion barrier to the pollutant (Lauren, Mc Donald, 1985; Van Heerden, Vosloo, Nikinmaa, 2004). Similarly, fusion of adjacent secondary lamellae as a consequence of edema could lead to telangiectasis, which is a characteristic pathologic feature of compromised gills associated with physical or chemical damage (Robert, 2001). However, such structural changes are reported to be non-toxicant specific (Meyer, Hendricks, 1985), which could be mere stress response of fish, to toxicants exposures (Gabriel et al., 2007). The effect of sniper 1000EC that brought about edema, hyperplasia and laceration of gill lamella explains why fishermen used sniper 1000EC indiscriminately causing heavy fish kills as it destroys the gills, the major respiratory and food filtering organ in fish (Abubakar, 2013). It was recognized that liver is difficult to analyse due to its high histological variability (Kotin, 1967). However, Myers, Landahi, Krahn, Johnson, McCain (1991) and Myers, Olson, Johnson, Stehr, Varansi (1992) have described the effects of different toxicants on the livers of various fish species. They showed that the liver distortions developed gradually over the time of exposure and that this varies from individual fishes. They also showed that it is possible that liver could regenerate and recover from those distortions. In this study, the histopathologies of the liver of $C$. gariepinus were carried out with a view to explaining the toxic mechanism of sniper 1000EC.

The toxicant caused alterations of the liver parenchyma, such as vacuolization and necrosis. These alterations were often associated with a degenerative- necrotic condition (Myers, Rhodes, McCain, 1987). This is in agreement with the reports of Omoregie, Ufodike (1990) and Auta (2001) who separately reported reduced liver vacoulation in Oreochromisniloticus exposed to actellic 25EC, paraquat and dimethoate respectively.The reduced vacoulation of hepatocytes may be due to fatty degeneration (Thiyagarajah, Grizzle, 1985; Auta, 2001; Langiano, Martinez, 2008). Vacuolation of hepatocytes with pycknotic (condensed) nuclei in the liver was most likely due to deposition of glycogen and lipid (Myers et al., 1987) as a result of hepatotoxicity induced by 
the presence of the toxicant and/or reduced food intake (Khan, Kiceniuk, 1988). Ferguson (1989) observed that a common morphologic response of fish liver to toxicity is the loss of hepatic glycogen and/or lipid. This condition according to Wolfe and Wolfe (2005) might have occurred by direct intoxication or it might have occurred secondarily to deceased body condition caused by stress or concurrent disease. Furthermore, the authors noted paradoxically that toxic exposure might also result in the accumulation of fats as recorded in this study.

The steatosis and necrosis were similar to those reported for fish caught in contaminated water or those exposed to various chemicals under laboratory conditions (Brand, Fink, Bengeyfield, Birtwel, Mc Allister, 2001; Rudolph, Yanez, Troncoso, 2001; Marty, Hoffinamn, Okihiro, Hepler, Hanes, 2003; Fafioye, Adebisi, Fagade, 2004; Koehler, 2004; Olojo, Olurin, Mbaka, Oluwemimo, 2005; Camargo, Martinez, 2007; Wahbi, El-Greishy, 2007; Aniladevi, Philip, Smitha, Bhanu, Jose, 2008). Fatty degeneration of the liver (haemosiderosis/steatosis) recorded in the liver of the exposed fish might be suggestive of metabolic disorders and it was commonly associated with dietary deficiency in response to xenobiotic (Myers et al., 1987). These changes are normally reported in disease organisms or those exposed to toxicants (Khan, Kiceniuk, 1988; Hawkins, Walleewrr, Orerstreet, Lyte, Lyte, 1988; Ogbulie, Okpkwasili, 1999). It might have resulted from disturbances in any of the steps in the sequence of the events from fatty acid entry to lipoprotein exit (Mitchell, Cotran, 2004). The degree of fatty changes in the exposed species exceeded that of the control implicating the toxicant as being responsible for the change. Lipid or glycogen vacuolation suggested the accumulation of triglycerides usually within the hepatocytes and may be responsible for the hepatocyte enlargement/hyalination (Wolf, Wolf, 2005). Steatosis has been correlated with neoplasms; however, its role in the progression of lesions towards neoplasm formation in fish was not well understood (McCain et al., 1982). Similar changes have been reported in the liver of Astyanax sp exposed to WSFs of crude oil (Akaishi et al., 2004). Percafluviatilis and gold fish exposed to oil seed process affected water (Nero et al., 2006), centrolobular necrotic change was the main change in the species exposed to the toxicant and agrees with the observation of Popp (1991) who suggested that the distribution of the interstitial system in the liver resulting in a higher concentration of the toxicant in the centrolobular region account for the occurrence and frequency of centrolobular toxicity.

The necrosis of the liver tissue might be due to inability of the fish to regenerate new liver cells due to the effect of sniper 1000EC. Several studies have reported that chronic accumulation of some toxicant in fish livers causes hepatocyte lysis, cirrhosis and eventually death (Pourahamad, O’Brien, 2000; Varanka, Rojik, Varanka, Nemcsók, Ábrahám, 2001). The kidney has been established as one of the principal site of erythropoietin production (Gordon, Zanjani, 1970). As in higher vertebrates, the kidneys of fish perform an important function related to electrolyte and water balance and maintenance of a stable internal environment. Thurston, Russo and Smith (1978) reported mild hydrophobic degeneration in renal tubule. The hydrophobic degeneration observed in the kidneys of the exposed fish species might be due to an increase in the permeability of fish tissues to water, and increased urine out put as reported by Lloyd and Orr (1969) for rainbow trout. Following the exposure of the fish to the toxicant, histological alterations have been found at the level of tubular epithelium (Teh et al., 1997). Ortiz, de Canales and Sarasquete (2003) found kidneys of exposed fish to have received the largest proportion of post-branchial blood, and therefore renal lesions may be good indicators of environmental pollution. Any effects on the kidney are likely to lead to major problems of anaemia and a lack of new blood cells formation. In this study, there was marked diffused tubular necrosis, hyperplasia of interstitial haemopoietic tissues. 
The changes recorded in the kidney section from exposed fish were similar to those caused by petroleum in English sole (McCain et al., 1978) and rats (Dede, Kagbo, 2001) and C.gariepinus exposed to plant extracts (Onusiruka, Ufodike, 2000; Fafioye et al., 2004) for various periods. Peripheral blood and cephalic kidney of turbot, Scophthalmusmaximus and Atlantic cod, Gadusmorus had micronuclei and severe nuclei abnormality such as nuclear buds, binucleated and nonylphenol (Barsiene, Dedonvte, Rybakovas, Anderson, 2006). Exposure, such as changes in kidney tubules particularly at the highest concentration recorded in this study might greatly impair the infiltration functions of the kidney with grave consequences for the exposed fish. However, the onset development and extent of these changes might be toxicant concentration and exposure time dependent.

\section{Conclusion}

In this study, alterations in gills, livers and kidney in the exposed fish species were associated with the effects of different concentrations of sniper 1000EC with LD50 of $15 \mathrm{mg} / \mathrm{l}$. By this context, smipper at $15 \mathrm{mg} / \mathrm{l}$ causes significant damage to fish tissue and hence be prevented and prohibited for fishing.

\section{References}

Abubakar, M.I. (2012). Comparative growth and survival rate of the African Catfish (Clarias gariepinus) larvae reared in water sourced from Stream and Tap water. Journal of Biological Sciences and Bioconservation, 4, 32-37.

Abubakar, M.I. (2013). Toxicity of 2, 3-dichlorovinyl dimethyl phosphate (Sniper 1000EC) on Clarias gariepinus (Burchell, 1822) and Oreochromis niloticus (Trewavas, 1983) under laboratory conditions. Unpublished Ph.D. Thesis, Department of Aquaculture and Fisheries Management. Federal University of Agriculture, Abeokuta, Nigeria.

Abubakar, M.I., Adeshina, I. (2019). Heavy Metals Contamination in the Tissues of Clarias gariepinus (Burchell, 1822) Obtained from Two Earthen Dams (Asa and University of Ilorin Dams) in Kwara State of Nigeria. Harran University Journal of Faculty of Veterinary Medicine, 8, 26-32.

Adeshina, I., Jenyo-Oni, A., Emikpe, B.O., Ajani, E.K., Abdel-Tawwab, M. (2019). Stimulatory effect of dietary clove, Eugenia caryophyllata, bud extract on growth performance, nutrient utilization, antioxidant capacity, and tolerance of African catfish, Clarias gariepinus (B.), to Aeromonas hydrophila infection. Journal of the World Aquaculture Society, 1-16. DOI: 10.1111/jwas.12565.

Akaishi, F.M., De, H.C., Assis, S.C., Jaakobi, D.R., Eiras-Stofella, S.D., St. Jean, S.C., Couteany, E.F., Lima, A.L., Wagener, A.L., Ribairo, C.A. (2004). Morphological and neurotoxicological findings in tropical freshwater fish (Astyanax $s p$ ) after waterboren and acute exposure to water soluble fraction of crude oil. Archives Environment Contamination and Toxicology, 46, 244-253.

Aniladevi, K.P., Philip, B., Smitha, V., Bhanu, SV., Jose, J. (2008). Histopathological effects on Oreochromis mossambicus (Tilapia) exposed to chlorpyrifos. Journal of Environment and Research and Development, 2, 553-559.

Auta, J. (2001). Toxicity of Dimethoate to Juveniles of Oreochromis nilotius (Trewavas) and Clarias gariepinus (Tengels). Ph.D. Thesis. Biological Sciences Department, Ahmadu Bello University, Zaria, Nigeria.

Banerjee, T.K. (2007). Histopathology of respiratory organs of certain air-breathingfish of India. Fish Physiology and Biochemistry, 33, 441-454. 
Barsiene, J.V., Dedonvte, A., Rybakovas, L., Anderson, O.K. (2006). Investigation of micronuclei and other nuclear abnormalities in peripheral bloodand kidney of marine fish. Toxicology, 78, 99-104.

Brand, D.G., Fink, R., Bengeyfield, W., Birtwel, I.K., McAllister, C.D. (2001). Salt water acclimated pink salmon fry (Oncorhynchus gorbuscha) develop stress related visceral lesions after 10-days exposure to sublethal concentrations of the water soluble fraction of North slope crude oil. Toxicology and Pathology, 29, 574-584.

Bucke, D. (1989). Histopathology. In: B. Austin, D.A. Austin (eds.), Methods for microbiological examination of fish and shellfish. West Sussex, England, Ellis Horwood.

Camargo, M.M., Martinez, C.B. (2007). Histopathology of gills, kidney and liver of a Neotropical fish caged in an urban stream. Neotrop. Ichthyological, 5, 327-336.

Camargo, M.M.P., Martinez, C.B.R. (2007). Histopathology of gills, kidney and liver of a neotropical fish caged in an urban stream. Neotropical Ichtyological, 5, 327-336.

Cavaco, J.E.B., Van Baal, J., Van Dijk, W., Hassing, G.A.M., Goos, H.J., Schulz, R.W. (2001). Steroid hormones stimulate gonadotrophs in Juvenile male African catfish (Clarias gariepinus). Biological Reproduction, 64, 1358-1364.

Chevailer, G., Gauthier, L., Moreau, G. (1985). Histopathological and electron microscopicstudies of gills of brook trout. Salvelinus fontinalis, from acidified lakes. Canadian Journal of Zoology, 63, 2062-2070.

Daye, P.G., Garside, E.T. (1976). Histopathologic changes in surface tissues of brook trout.Salvelinus fontinalis (Mitchill), exposed to acute and chronic level of $\mathrm{pH}$. Canadian Journal of Zoology, 54, $2140-2155$.

Dede, E.B., Kagbo, H.D. (2001). Investigation of acute toxicological effects of dieselin rat (Rattusrattus) using histopathological methods. Journal of Applied Science and Environmental Management, 5, 83-84.

Drishya, M.K., Binu-Kumari, S., Mohan-Kumar, M., Ambikadevi, A.P., Aswin, B. (2016). Histopathological changes in the gills of fresh water fish, Catla catla exposed to electroplating effluent. International Journal of Fisheries and Aquatic Studies, 4, 13-16.

Eddy, F.B. (1982). Osmotic and ionic regulation in captive fish with particular reference to salimonids. Comparative Biochemistryand Physiology, 72, 125-141.

Eller, L.L. (1971). Histopathologic lesions in Culthroat trout (Salmo Clark) exposedchronically to the insecticide endrin. American Journal of Pathology, 64-321.

Fafioye, O.O., Adebisi, A.A., Fagade, S.O. (2004). Toxicity of Parkia biglobosa and Raphia vinifera extracts on Clarias gariepinus juveniles. African Journal of Biotechnology, 3, 627-630.

Fanta, E., Rios, F.S., Romao, S., Vaaianna, A.C.C., Freiberger, S. (2003). Histopathology of fish Corydoras paleatus contaminated with sublethal levels of organophosphorus in water and food. Ecotoxicology and Environmental Safety, 54, 119-130.

Ferguson, H.W. (1989). Systemic pathology of fish: a text and atlas of comparative tissue responses in diseases of teleosts. IOWA. State Univ. Press. Ames.

Gabriel, U.U., Amakiri, E.U., Ezeri, G.N. (2007). Haematology and gill pathology of Clarias gariepinus exposed to refined petroleum oil, kerosene. Under laboratory conditions. Journal Animal Veterinary Advances, 6, 461-465.

Gernhofer, M., Pawet, M., Schramm, M., Muller, E., Triebskorn, R. (2001). Ultrastructural biomarkers as tools to characterize the health status of fish in contaminated streams. Journal of Aquatic Ecosystem, Stress and Recovery, 8, 241-260.

Gordon, A.S., Zanjani, E.D. (1970). Hormone and erythropoiesis. In: T.J. Greenwalt, G.A. Jameson (eds.), Formation anddestruction of blood cells (pp. 34-64). Philadelphia: Lippincott. 
Hawkins, W.E., Walleewrr, R.M., Orerstreet, R.M., Lyte, T.F., Lyte, J.S. (1988). Dose related carcinogenic effects of water-borne benzo (a) Pyreneon livers of twosmall fish species. Ecotoxicology Environmental Safety, 166, 219-231.

Hinton, D.E., Baumann, P.C., Gardner, D.R., Hawkins, W.E., Hendricks, J.D., Murchelano, R.A., Okihiro, M.S. (1992). Histopathologic biomarkers. In: R. Huggert, R. Kimerle, P. Mehrle, H. Bergman (eds), Biomarkers-biochemical, physiological and histological markers of anthropogenic stress (pp. 155195). Boca Raton: Lewis Publishers.

Hinton, D.E., Lauren, D.J. (1990). Liver structural alterations accompanying chronic toxicity in fishes: potential biomarkers of exposure. In: J.F. McCarthy, L.R. Shugart (eds.), Biomarkers of Environmental Contamination P(pp. 51--65.). Boca Raton: Lewis Publishers.

Hossler, F.E., Harpole, J.H., King, J.A. (1986). The gill arch of the striped bass Mironesaxatilia I. surface structure. Journal of Submicrobiology and Cytology, 18, 519-528.

Khan, R.A., Kicenuik, K. (1988). Effect of petroleum hydrocarbons on monogencid Parasitizing Atlantic cod, Gadus morhua. Bulletin of Environment and Contamination Toxicology, 41, 91-100.

Koehler, A., Deisemann, H., Lauritzen, B. (2004). Histological and cytochemical indices of toxic injury in the liver of dab Limanda limanda. Marine Ecology and Progessive Service, 91, 141-153.

Kolbasi, T.B., Burcu, I.,Ucuncu, S., Onen, O. (2009). The effects of sodium perchlorate on the liver of Molly fish (Poecilias phenops, Cyprinidae, Teleostei). African Journal of Biotechnology, 8, 2640-2644.

Kotin, P. (1967). Synopsis. Trout Hepatoma: Research Conference Paper, 70, 193-199.

Langiano, V.D.C., Martinez, C.B.R. (2008). Toxicity and effects of aglyphosate-based herbicide on the Neotropical fish Prochilo duslineatus. Comparative Biochemistry. Physiology Cancer Toxicology and Pharmacology, 147, 222-231.

Lauren, D.J., McDonald, D.G. (1985). Effect of copper on bronchial ion regulation in the rainbow trout, Salmon gairdneri Richardson. Modulation by water hardness and $\mathrm{P}^{\mathrm{H}}$. J Comp Phyiol, 155 B, 635-644.

Laurent, P., Dunel, S. (1980). Morphology of gill epithelia in fish. American Journal of Physiology, 238, $147-159$.

Laurent, P. (1984). Gill internal morphology: Part A. In: W.S. Hoar, and D.J. Randall (Eeds.)., Anatomy, gas transfer and acid regulation (pp. 73-183). New York-London: Academic press.

Llyod, R., Orr, L.D. (1969). The diuretic response by rainbow trout to sub-lethalconcentrations of ammonia. Water Research, 3, 334-335.

Marty, G.D., Hoffinamn, A., Okihiro, M.S., Hepler, K., Hanes, D. (2003). Retrospective analysis. Bile hydrocarbons and histopathology of demersel rockfish in Prince William sound. Alaska. After the Exxon spill. Marine Environment and Research, 56, 569-584.

Mastan, S., Ramayya, P.J. (2010). Biochemical profile of Channa gachua (Ham) exposed to sublethal doses of Dichlorvos (DDVP). The Internet Journal of Toxicology, 8.

McCain, B.B., Myers, U., Varanasi, D.W., Brown, L.D., Rhodes, E.D., Grondund, D.G., Ellist, W.A., Palsson, H.O., Malins, D.C. (1982). Pathology of two species of flat fish from urban estuary of Puget sound. Interagency Energy. Environment Research and Development Programme Report. EPA, 60017-001.

Meyers, T.R., Hendricks, J.D. (1985). Histopathology. In: G.M. Rand, R. Petrocellis (eds.), Fundamentals of Aquatic Toxicology; methods and Applications (pp. 283-331). Washington, DC: Hemisphere publishing corp.

Mitchell, R.N., Cotran, R.S. (2004). Cell injury adaptation and death. In: V. Kumar (ed.), Robbins, Basic pathology (pp. 3-32). New Delihi: Saunders.

Myers, M.S., Landahi, J.J., Krahn, M.M., Johnson, L.L., McCain, B.B. (1991). Relationship between hepatic lesions the than neoplasm in sub adult flatfishfrom Puget sound, Washington: relationship with indices of contaminant exposure. Marine Environment and Research, 34, 45-51. 
Myers, M.S., Olson, O.P., Johnson, L.L., Stehr, C.S., Varansi, U. (1992). Hepatic neoplasm and related lesions and exposure to toxic chemicals in Marine fish from U.S. West. Environment and Health Perspective, 90, 7-15.

Myers, M.S., Rhodes, L.D., McCain, B.B. (1987). Pathologicanatomy and patterns of occurrence of hepaticneoplasms, putative preneoplastic lesions, and other iodiopathic hepatic conditions English sole (Parophrysvetulus) from Puget Sound, Washington. Journal National Cancer Institute, 78, 333-363.

Nero, V., Farwell, A., Lister, A., Vander Kraek, G., Lee, L.E., Van, T., Meer, M.D., Dixon, D.G. (2006). Gill and liver histopathological changes in yellow perch (Perca flavescenes) and gold fish (Carassina auratus) exposed to oil sands process affected water. Ecotoxicology Environment and Safety, 63, 365-377.

Ogbulie, J.N., Okpokwasili, G.C. (1999). Haematological and Histological responses of Clarias gariepinus and Heterobranchus bidonsalis to some bacterial diseasein River State, Nigeria. Journal of National Science Foundation of Sri lanka, 27, 1-16.

Olojo, E.A.A., Olurin, K.B., Mbaka, G., Oluwemimo, A.D. (2005). Histopathology of the gill and liver tissues of the African catfish Clarias gariepinus exposed to lead. African Journal of Biotechnology, $4,117-122$.

Olson, K.R. (1996). Scanning electron microscopy of fish gill. In: J.S. Dattamunschi, H.M. Dutta (eds.), Fish morphology; horizon of new research.

Omoregie, E., Ufodike, E.B.C., Keke, I.R. (1990). Tissue chemistry of O.niloticus Exposed to sub lethal concentrations of Gammalin 20 and Actellic 25EC. Journal of Aquatic Sciences, 9, 35-41.

Onusiriuka, B.C. (2002). Effects of sublethal concentrations of formalin on weight gainin the African catfish, Clarias gariepinus (Tengel). Journal of Aquatic sciences, 17, 66-68.

Ortiz, J.B., de Canales, M.L.G., Sarasquete, C. (2003). Histopathological changes induced by lindane (gamma-HCH) in various organs of fishes. Science Marine, 67, 53-61.

Popp, J.A. (1991). Hepatobiliary system. In: N. Haschek, N and C.G. Roussaaux E(eds.), Hand book of toxicological pathology (pp. 279-314). Philadelphia, USA: Academic Press Inc.

Pourahamad, J., O'Brien, P.J. (2000). A comparison of hepatocytecytotoxic mechanisms for Cu2+, an$\mathrm{dCd} 2+$. Toxicology, 143, 263-273.

Roberts, R.J. (2001). Fish pathology ( $3^{\text {rd }}$ dn). London: bailliere Tindall.

Rudolph, A., Yanez, R.,Troncoso, L. (2001). Effects of exposure of Oncorhynchus mykiss to the wateraccommodated fraction of petroleum hydrocarbons. Bulletin of Environment Contamination and Toxicology, 66, 400-406.

Schwaiger, J., Wanke, R., Adam, S., Pawert, M., Honnen, W., Triebskorn, R. (1997). The use of histopathological indicators to evaluate contaminant-related stress in fish. Journal of Aquatic ecosystem, Stress and Recovery, 6, 75-86.

Tech, S.J., Adams, S.M., Hinton, D.E. (1997). Histopathological biomarkers in feral freshwater fish populations exposed to different types of contaminant stress. Aquatic Toxicology, 37, 51-70.

Thiyagarajah, A., Grizzle, J.M. (1985). Pathology of diethyinitrosamine toxicity offish, Rivulus marmoratus. JEPTOG, 212-232.

Thophon, S., Kruatrachue, M., Upathan, E.S., Pokethitiyook, P., Sahaphong, S., Jarikhuan, S. (2003). Histopathological alterations of White seabass, Lates calcarifer in acute and subchronic cadmium exposure. Environmental Pollution, 121, 307-320.

Thurston, R.V., Russo, R., Smith, C.E. (1978). Acute toxicity of ammonia and nitriteto cut throat trout fry. Transactions of American Fisheries Society, 107, 361-368.

Turala, I.A. (1983). Relationships between secondary lamellar structure and dorsal aortic Oxygen tension in Salmo girdner with gills damaged by zinc. Annals of Zoology Fenn, 20, 235-238. 
Van Heerden, D., Vosloo, A., Nikinmaa, M. (2004). Effects of short-term copper exposure on gill structure, me thallothionein and hypoxia-inducible factor-1. (HIF-1-) levels in rainbow trout (Oncorhyynchus mykiss). Aquatic Toxicology, 69, 271-280.

Van Valin, C.C., Andrews, A.K., Eller, L.L. (1968). Some effects of mirex on twowarm-water sites. Transition American Fisheries Society, 97-185.

Varanka, Z., Rojik, I., Varanka, I., Nemcsók, J., Ábrahám, M. (2001). Biochemical and Morphological changes in carp (Cyprinus carpio L.) liver following exposure to copper sulfate and tannic acid. Comparative Biochemistry and Physiology, 128, 467-478.

Wahbi, O.M., El-Greisy, Z.A. (2007). Comperative impact of different waste sources onthe the reproductive parameters and histology of gonads, liver and pituitary gland of Siganus rivaltus. Journal of Applied Science Research, 3, 236-244.

Wester, P.W., Canton, J.H. (1991). The usefulness of histopathalogy in aquatictoxicity studies. Comparative Biochemistry and Physiology, 100, 115-117.

Wolfe, J.C., Wolfe, J.W. (2005). A brief review of non neoplastic hepatic toxicityin fish. Toxicology and Pathology, 33, 75-83.

Cite as: Abubakar, M.I., Adeshina, I., Abdulraheem, I., Abdulsalami, S. (2019). Histopathology of the gills, livers and kidney of Clarias gariepinus (Burchell, 1822) exposed to sniper 1000EC under laboratory conditions. Acta Biologica, 26, 19-30. DOI: 10.18276/ab.2019.26-02. 